\title{
Violence, Protection and Commerce
}

\author{
Corsairing and ars piratica in the Early Modern \\ Mediterranean \\ Wolfgang Kaiser and Guillaume Calafat
}

Like other maritime spaces, and indeed even large oceans such as the Indian Ocean, the Mediterranean was not at all a 'no man's sea' - as the sea in general appears, opposed to territorial conquest and occupation of land, in a prominent way in Carl Schmitt's opposition between a terrestrian and a 'free maritime' spatial order. ${ }^{1}$ Large oceanic spaces such as the Indian Ocean and smaller ones such as the Mediterranean were both culturally highly saturated and legally regulated spaces. ${ }^{2}$ The Inner Sea has even been considered as a matrix of the legal and political scenario of imposition of the Roman 'policy of the sea' that had efficiently guaranteed free circulation and trade by eliminating the pirates-Cicero's 'enemy of mankind' ${ }^{3}$ - who formerly had infected the Mediterranean. Convergence between Roman and Islamic legal traditions seemed to ensure, after the decline of the Roman Empire, a zone of free maritime navigation and trade. ${ }^{4}$ This 'Inner Sea' was made of other regional inner seas, gulfs, channels and straits - as represented (a shared feature) in Early Modern European, Islamic and Ottoman cartography. The Mediterranean has been, from the medieval glossators of Roman Law to the main protagonists of what has been called the 'hundred years battle of the books' 5 of the sixteenth and seventeenth century, conducted most prominently by Hugo Grotius, Serafim de Freitas and John Selden, a rich fund of examples and situations, and indeed a laboratory to forge, according to specific contexts and divergent interests, in a kind of ars combinatoria, both the arguments for free navigation at sea and free use of its riches and, on the contrary, legitimate control of territorial waters. It is with the emergent concept of 'jurisdiction', to fight against piracy and protect free navigation and free use of maritime resources, that the practical manifestations of imperium, that is, the full 


\section{Proof}

exercise of power and a domanial appropriation of a maritime space, were argued and justified.

Both interpretations combine the obligation of protection (against piracy) and the right to exercise justice (jurisdiction). The claim of a dominium maris signified the definition of maritime boundaries, a liberty of navigation under control and constraint, reserved fishing rights and the right to impose taxes on passing ships. These were competing claims: Venice's maritime dominion, the Golfo di Venetia (as the Adriatic Sea was mainly indicated on contemporary maps), passionately defended by for example Paolo Sarpi during the 1610s, ${ }^{6}$ was contested by the jurists in the Kingdom of Naples who reduced it to the near coastal zone (the district between Venice and Chioggia). The claim of a dominium maris could make the common distinction between controlled territorial waters and free 'high seas' inappropriate in the Mediterranean, for instance in the case of medieval Genoa. The Signoria claimed not only to control the navigation in its coastal waters (juxta terram) but also to exercise a regional hegemony in the 'sea of Genoa' by defending navigation and the right to exclude another (ius excludendo altri) on the High Sea's (per pelagus) lanes and constraining competitors to a coastal passage and to the payment of a tax in exchange of protection. In this complicated Mediterranean situation, it seems to be difficult to characterise corsairing that was after all part of a whole set of forms of exercising legitimate power, as 'extra-territorial violence'. ${ }^{7}$

Other elements add to the complexity of the medieval and Early Modern Mediterranean: the competition between European powers, including the Atlantic powers, with their own legal traditions, including the customary maritime traditions, compiled in late medieval and Early Modern times, such as the Catalan Consolat de Mar in the Mediterranean and the Rôles d'Oléron in the Atlantic and the copresence of Roman, Byzantine and Islamic law, often neglected in the narratives of the history of the law of nations and maritime law. ${ }^{8} \mathrm{~A}$ whole literature has described the process of increasing state control and 'civilising' warfare between European powers in the medieval period. Yet, recent research, mainly concerned with intra-European wars, has shed new light on the reality of warfare and stressed the fact that violence in the Early Modern period was not random, brutal and irrational, but followed highly ritualised practices in wartime, including suspension of conflict, avoiding violence by payment and maintaining of communication and trade. ${ }^{9}$ This is also true for the conflicts opposing the European powers to the Ottoman Empire, the rising force in the Early Modern Mediterranean, 


\section{Proof}

Corsairing in the Early Modern Mediterranean

71

contested by the Habsburg Monarchy and the old and new (Dutch and English) European and indeed Mediterranean powers.

The complexity of different levels and conflicting goals makes the Mediterranean an interesting and at the same time difficult case: competitive empire-building - the Habsburg composite monarchy and intercontinental empire, the expansion of the Ottoman Empire, Portuguese, English and Dutch empire-building in Asia and the Atlantic - the making of territorial states and the competition for trade in the Mediterranean. Last but not least, conflict and cooperation on the regional and local level were intertwined. In the late medieval and Early Modern Mediterranean there was no hegemonic power and there was no synchronised chronology that could structure a single master narrative, whether in terms of a 'clash' between Islam and Christendom or of progressive violence-controlling and state-building or the process of quasi-natural European domination of the Mediterranean. Thus, instead of a synthetic overview, we will discuss some contrasting features of corsairing and commerce, of violence and state-building. We will argue that violence indeed was a stimulus of exchange in the late medieval and Early Modern Mediterranean. In particular, the conflictual relations between, on the one hand, the North African Regencies of the Ottoman Empire, the so-called Barbary States, and, on the other hand, the European powers constituted a domain of regulation and legal innovation.

\section{Piracy, corsairing and naval warfare}

Ars piratica (the art of piracy) was a traditional feature of Mediterranean port cities. It was an important part of the urban economy of Béjaïa on the Algerian shore in the fourteenth and fifteenth centuries. Those who engaged in it were people of modest origin - workers (lavrador), retailers (tender) or artisans in the textile sector (canelador, texidor) - which means that the exercise of piraticam artem was probably a part-time activity. ${ }^{10}$ In the case of Béjaïa, piracy was directed in particular towards the coastal regions of Andalusia and Valencia and its goal was, in the context of the violent conflict called Reconquista in European historiography, to seize booty with maritime operations or terrestrial razzias (raids). Booty especially meant human booty, that is, captives to be sold into slavery or, expecting higher gains, offered to be ransomed by their families or institutions of their hometowns or countries.

The terms 'pirate' and 'corsair' seem to be used indistinctively in the sources, including the granting of licences for corsairing by the king 


\section{Proof}

in late medieval Aragon. ${ }^{11}$ Furthermore, the flourishing of 'piracy' or 'corsairing' has been linked to both the weakening of state power - for example, in Sicily after 1350, where autonomous lordships seem to have developed the practice of piraticam artem ${ }^{12}$ - or, on the contrary, has been related to enforced political control by the authorities, such as in the Béjaiia of the fourteenth and fifteenth centuries and under the Hafsid dynasty in Ifriqiya (Tunisia). ${ }^{13}$ We find the same simultaneous use of the two terms 'corsairing' and 'piracy' also in Sicilian sources of the sixteenth century where citizens of Trapani, in this case, too, people of modest social position, fishermen and sailors, engaged in corsairing and piracy in Barbary (exercendi cursum et artem piraticam in partibus Barbariae) with a licence from the authorities. ${ }^{14}$

Piratical activity was endemic in the coastal regions of the Mediterranean, linked to economic difficulties and political crisis, civil war and weak state control, such as in France during the religious wars in the second half of the sixteenth century. The famous Spanish composer Francisco Guerrero was, for example, captured twice in 1589 on the return from his pilgrimage to Jerusalem, by impoverished French gentlemen - 'Lutherans' in his eyes - first in the Camargue and a second time on the shores of the Languedoc: 'During our travel . . . the danger did not come from the Turks, the Moors or the Arabs, but exclusively from the French. ${ }^{15}$

It is the licence issued by an authority considered as legitimately exercising - indeed delegating - sovereign rights of repression (represailles) against subjects of the enemy that makes the difference between an ordinary sea robber and a corsair. In the context of European maritime warfare, merchants and other people invested risk capital in artem piraticam exercendi ${ }^{16}$ directed for instance against the Spaniards, Catalans, Genoese or Venetians, as the enemies were spelled out in a lettre de marque issued in 1512 in Provence. ${ }^{17}$

Corsairing may thus be considered as institutionalised, legitimate and regulated violence. ${ }^{18}$ But why do we find in contemporary sources simultaneously the use of the term piratica ars? It seems that this was meant to designate the shared goal of this specific activity - booty. ${ }^{19}$ As for pirates, the objective of corsairs was primarily the rich cargo of merchant ships and captives, not warfare against other corsairs or armed naval forces. This was the argument of corsairs from Provence in the sixteenth century who refused to fight against other corsairs: 'in the fight of corsair against corsair you just win empty casks' (de cossari à cossari non si gassanho que barilh). ${ }^{20}$ Booty became a legitimate prize, stated a posteriori, in the context of justified warfare and the claim to exercise sovereign rights of represailles. 


\section{Proof}

Corsairing in the Early Modern Mediterranean

Licenced corsairing offered to these entrepreneurs of violence - as to the condottieri of the Italian Renaissance - an opportunity to acquire reputation and legitimacy. At the same time, princes, sovereigns, authorities could thus cope with their weakness by delegating - a dissimulating term, as they were delegating something that they were incapable of making use of - the use of public power to licenced private persons who thus become public actors. The instrumental use of violence, as corsairing against enemies and competing powers has been characterised, is an important part of a mercantilist politics of power and an essential element of empire-building and state-formation through the offer of efficient protection. In the Indian Ocean, the Portuguese sold licences called cartazes - an Arab word integrated into Portuguese in the sixteenth century - that is, protection for ships against violence, foremostly the violence of the protectors themselves. As put by Jan Glete: 'Europeans used violence to get monopoly rights to trade, they sold protection to Asian and European merchants and ships and they sold their superior technology for war to Asians who were in conflict with other Europeans and other Asians. ${ }^{21}$

In the Mediterranean, weakening the enemy through raids on the coasts, capturing people and the seizure of ships at sea, was a generalised practice of competing powers that pretended to sovereignty, that is, to the power to define what was legitimate corsairing and what was criminal piracy and, if useful for them, to keep this difference unclear. ${ }^{22}$ Efficient protection ensured lesser insurance costs, a protection rent and, as Frederic C. Lane has put it, 'profits from power' for those who offered protection. ${ }^{23}$ This explanatory model still seems useful to uncover the issues present in the competition of European powers in Constantinople to obtain the best terms of trade and efficient protection in the Ottoman Empire. Moreover, the model highlights the role of corsairing as part of the naval warfare between the European powers in the Mediterranean. ${ }^{24}$ The use of private investment in the exercise of public violence through corsairing and the control of those entrepreneurs of violence was part of Early Modern state-formation as private investment in state activities. The use of 'private ships of war' was a weapon especially of minor sea powers or a consequence of the consideration of naval warfare as secondary. Corsairing became important in the War of the Great Alliance (1689-97) in which French corsairs - the most prominent of whom was Jean Bart - captured about 4000 ships of the enemy. ${ }^{25}$ During the great European wars at the end of the seventeenth and beginning of the eighteenth centuries, licenced Mallorquin and French corsairs were massively present in the Mediterranean 


\section{Proof}

theatres of war. ${ }^{26}$ Simultaneously, naval warfare during the Anglo-Dutch Wars of the seventeenth century also took place in the Mediterranean, with the Battle of Livorno in 1653 and the subsequent installation of the Royal Navy from the 1670s in Livorno, 1704 in Gibraltar and 1708 in Menorca.

\section{North African corsairing and its impact}

To what extent did the institutionalisation of piracy show signs of embryonic or even more developed state-formation in sixteenth-century North Africa and the Western Mediterranean? Corsairing shaped the commercial and diplomatic relations between Southern Europe (Iberia, the French kingdom and the Italian regional states), the Ottoman Empire and its dependent territories in North Africa. Fernand Braudel has called this endemic activity a 'secondary form of war' and indicated as its apogee the 'century of corsairing', from the Battle of Lepanto in 1571 to the end of the seventeenth century. ${ }^{27}$

Since at least the fifteenth century, in the context of the Reconquista, Muslim corsairs supported by the Ottomans operated from North African ports against Spanish ships. ${ }^{28}$ After 1492 and for almost seventy years, North Africa became a theatre of violent conflicts between the Spaniards and the local sovereigns and authorities, from the Spanish conquest of Oran in 1509 up to the definite conquest of Tunis by 'Ulūc 'Alī in 1574. It was the conquest of Algiers by 'Arūdij and K $\underline{\text { hayr }}$ al-Dīn Barbarossa (two brothers from Mytilene/Lesbos), first in 1517 and 1519 and then definitively in 1529, combined with the occupation, assisted by Turkish janissaries sent by the Ottoman Sultan, of the Peñon of Algiers and the expulsion of the Spanish garrison there, which opened the way for the expansion of the Ottomans in North Africa. Algiers, Tunis (which was conquered definitively in 1574) and Tripoli (conquered in 1551) were integrated as peripheral Regencies in the Ottoman Empire. On the Christian side, the settlement of the Knights of St John at Malta, established in 1530, had the mission of fighting the Turk and the 'Barbaresques', thereby giving an impulse to corsairing, reinforced by the foundation of the Tuscan Military Order of St Stephen in 1561.

In the sixteenth-century Mediterranean, naval warfare (guerre d'escadre) and corsairing (guerre de course) - the latter of which included coastal raids that occasionally could reach considerable distances inland - were intimately linked or better, different aspects of the practice of maritime warfare. The Algerian, and later the Tunisian and Tripolitan, corsairs 


\section{Proof}

were sanctioned by the Ottomans and were integrated into and indeed commanded their marine forces. Khayr al-Dīn Barbarossa, the master of Algiers, was appointed First Governor (beylerbey) of the province of Algiers by the Ottoman Sultan and later Admiral (kapudan pasha) of the Ottoman fleet. After the naval battle of Preveza (1538), the victorious Ottoman fleet under the command of Khayr al-Dīn cooperated with the French fleet, on the basis of the alliance between the French king and the Sultan in Constantinople. The Ottoman fleet raided Mahon on Menorca, besieged Nizza, attacked Ostia and conquered the Isle of Lipari in 1544. Immediately afterwards, 700 prisoners were ransomed in the secondary ports near Messina and then in Messina itself, which was transformed, with the permission of the vice-king, for some days into a 'bazaar', that is a slave market where the captives were offered to be ransomed by their families. ${ }^{29}$

These coastal raids produced more captives than corsairing at sea and had demographical consequences in the areas concerned. Towns such as San Lucido (Calabria) or Vieste and Manfredonia in the Gargano (Puglia) experienced demographic losses of between 40 and 80 per cent. ${ }^{30}$ Coastal towns and settlements were most vulnerable, but spectacular raids, such as that in 1566 when 6000 Turks penetrated about a hundred kilometres into the hinterland of Francavilla (Puglia), showed that the corsairs had the capacity to launch attacks far inland. The goal of these raids was the capture of the local population - not necessarily to conduct them all into slavery, but to let them be ransomed directly by their families after their capture. The places where 'the white flag is erected and slaves are being ransomed ${ }^{\prime 31}$ was part of a local knowledge and has marked the local toponymy: in Early Modern Andalusia the practice of immediate ransoming was called alafia, originally from an Arabic word meaning 'grace', 'pardon'. In Melilla, a Spanish presidio (garrison) in Northern Africa, we still find a torre del Alafia.. ${ }^{32}$ The endemic practice of a partly terrestrian artem piraticam as a permanent threat is visible in popular belief and legend: for example, a black cat was considered in nineteenth-century Naples as a spy from Barbary. Ransom slavery was not a uniquely Mediterranean practice; it was also part of a specific frontier economy in borderlands between the AustroHungarian and the Ottoman empires. ${ }^{33}$ For the Mediterranean, Michel Fontenay has proposed to use the contemporary term corso to designate this form of state-sanctioned maritime violence, which blurs the distinction between corsairing and piracy. ${ }^{34}$

With the technological change at the beginning of the seventeenth century - the shift from the galley to the bertone (a three-rigged, 
originally North European, round-hulled sailing ship) ${ }^{35}$ - the trade with captives became more important and more profitable than the traditional slave trade (even if the French consul at Livorno in the seventeenth century continued to buy valid slaves for the king's galleys at Toulon and Marseilles). ${ }^{36}$ At the apogee of the Mediterranean corso in the seventeenth century, the corsairs from North Africa (Algiers, Tunis, Tripoli and the Moroccan port of Salé) armed about 100 ships of different types at any one time, while on the Christian side, estimates give about 40 ships. Due to technological change and the arrival of North European sailors converted to Islam, North African corsairing extended to the Atlantic and the English Channel. Converted corsairs such as Simon Romero from the Canary Islands, a famous captain ( $\left.\mathrm{ra}^{\prime} \bar{\imath} \mathrm{s}\right)$ of Algiers in the sixteenth century, operated between Algiers, Salé and the Canary Islands and cooperated in ransoming with English merchants residing in Cadiz who worked as alfaqueques or ransomers. ${ }^{37}$ The most spectacular operation of Algerian corsairs was the famous raid on Iceland in 1627, but more important was the threat exercised by North African corsairing on navigation in the Channel and on the Atlantic routes of Dutch and Hanseatic trade. ${ }^{38}$

In the Mediterranean, the threat of coastal raiding diminished in the seventeenth century when effective protection systems - equestrian patrols in Andalusia and improved fortifications and towers (the so-called Saracens towers) for defence and signalisation - came to cover the partly inhabited coastal zones of Andalusia, Liguria, Sardinia, Corsica and southern Italy. There were about 5000 towers in southern Italy and on the islands; in Sicily alone, historians have counted 137 towers, on average one tower about every eight to nine kilometres along the coast. ${ }^{39}$

Corsairing added to the difficulties inherent in cross-cultural commercial interactions between Muslim and Christian countries. But, paradoxically, far from being a mere economy of booty and plunder and an obstacle for mercantile exchanges, corsairing in the Mediterranean, with its concomitant trade in captives and other booty, offered a trading platform that crossed religious, legal and normative boundaries.

It is impossible to give an overall estimate of the economic impact of corsairing with regards to the global volume of seaborne trade. Contemporary sources tend naturally to overestimate the impact of corsairing. In the Western Mediterranean, the first decade of the seventeenth century, the years of the war of Candia (1645-69) and the last decade of the seventeenth century were periods of intense corsairing. For example, French sources give for Tunis about 10 ships captured in 1611-12, 18 French ships from 1652 to 1665 and 23 prizes from 1666 to 1672 . For 


\section{Proof}

Corsairing in the Early Modern Mediterranean

Algiers, an estimate gives 963 ships from 1613 to 1622, of which 447 were Dutch and 253 French. ${ }^{40}$ The Trinitarian Pierre Dan estimated that the Algerian corsairs from October 1628 to August 1634 had taken 80 French ships of different types. From 1674 to 1677, the Algerians captured 191 French ships. ${ }^{41}$ Wijnant de Keyzer, Dutch consul at Algiers, estimated that the Algerian corsairs between 1618 and 1620 had taken more than 100 Dutch ships, including 76 of 125 prizes in $1620 .{ }^{42}$ Finally, Thomas Baker, English consul at Tripoli, reported that Tripoli corsairs from 1679 to 1685 took 71 ships ( 27 French ships representing 74 per cent in terms of value). ${ }^{43}$ However impressive as these figures may seem, they represent only about 2 or 3 per cent of the total French commerce in the Mediterranean in the seventeenth century. ${ }^{44}$ French losses in the eighteenth century due to European corsairing were even more limited.

Fontenay and Lemnouar Merouche have given supplementary estimations of the impact of the 'corsairing industry' at Algiers and Malta. ${ }^{45}$ They conclude that even if the sister 'Republics of Corsairs' were substantially engaged in these violent enterprises, this sector never constituted the major economic domain and source of income. On the whole, the benefits of corsairing were realised through the recycling of the prizes (30 per cent) in the European ports of Marseilles, Genoa and Livorno. For Malta, Fontenay has calculated that the income of the landed property (600 commanderies) of the Knights of St John was always more important than the profits from corsairing. ${ }^{46}$ On the whole, investment in corsairing could be individually rewarding - Why not I? was the name of the ship of an English corsair in the Indian Ocean in the seventeenth century ${ }^{47}$ - but was globally deficit-producing. This is true also for the activities of the Tuscan Knights of St Stephen, charged with defending the Tuscan coasts and procuring slaves for the Tuscan galleys. They captured about 10,000 slaves during the sixteenth and the first half of the seventeenth centuries but declined afterwards as armament had become too expensive. ${ }^{48}$ This also explains why private investors, for instance in Malta, present in the seventeenth-century corsairing controlled by the Order of St John, turned their backs to it in the eighteenth century and preferred to invest in trade. ${ }^{49}$ Despite its mission to fight against the Muslims, the activities of the Knights of St John at Malta in the Eastern and Central Mediterranean were directed against the Greeks who could be subjects of the Ottoman Sultan but also of the Republic of St Mark, and thus threatened the Venetian trade more than the religious enemy. Consequently, the Knights of St John encountered severe opposition from Venice, France and the Papal States (Ancona), all interested in a peaceful Levant trade. ${ }^{50}$ 


\section{Proof}

It was the redistribution of wealth from the victims of corsairing to those who offered financial services and who organised the recovery or the recycling of ships and cargo that characterised the 'economy of ransoming'. ${ }^{51}$ It was a stimulus for trade and constituted a complementary and, in fact, securing element of normal trade and procured a religious justification for the papal bulls that banned trade with the 'infidel'. In this sector we frequently find commercial association across religious and cultural differences. Ransoming of captives was promoted with a variety of private and institutionalised initiatives that resulted in an increased demand for captives to ransom and created a dynamics of capture and inflated prices. We will probably never know how many captives were ransomed - private ransoming or the above mentioned ransoming 'on the spot' are particularly difficult to grasp - but if the figure of 1 million or so 'white slaves' seems to be exaggerated, ${ }^{52}$ the estimate of about 180,000 from 1574 to 1644 may well be too low. ${ }^{53}$

\section{Barbary legend and reality}

What was the impact of corsairing on state-formation? For the European powers, in the Mediterranean as in the Atlantic, the massive distribution of licences for corsairing, a current practice in French Mediterranean politics well into the eighteenth century, complemented official warfare, testifying to the difficulty of financing standing armies and permanent fleets.

It is in contemporary European discussion of the so-called Barbary States that we find an ambiguous and ideologically oriented treatment of piracy and corsairing. In fact, if European corsairs and the Knights of St John were considered as honourable warriors against the 'infidel', their brethren from North Africa were castigated as pirates. This labelling aimed to delegitimise the North African corsairs, although they had licences for corsairing from the pasha or bey and certificates from the French consul. The European discourse mobilised the semantic ambiguities of the term 'barbary', which could refer both to the land of the Berbers (that is, North Africa) and the adjective 'barbarian' in the sense of uncivilised. The labelling of the North African polities as Barbary also pointed to a presumed violent usurpation of power in Algiers and Tunis by the Barbarossa brothers, although in reality it was comparable to conquests by the Italian condottieri of the Renaissance.

The contemporary discourse on Algiers' 'Corsairs' Republic' and corsairing as a state-controlled enterprise and a supposed main source of income reflects this perception of an illegitimate regime based on 


\section{Proof}

Corsairing in the Early Modern Mediterranean

violence exercised by partly foreign forces (janissaries, 'renegade' corsairs or $r a^{\prime} \bar{\imath}$ s). In fact, corsairing was supported by the Ottoman authorities who benefited from corsairing (as in Europe or Malta): the pasha or bey received 10 per cent (Tunis) or 12 per cent (Algiers) of the booty, but concerning the prizes sold by auction, half went to the private investors and the other half was divided between the captain, the janissaries and the sailors. The dominant forces also practiced a regime of violent taxcollecting through military campaigns in the North African hinterlands, the revenues of which were used for the payment of the janissaries, for instance. Against this background, modern historians from the Maghreb have analysed a particular 'social formation' in Tunis, ${ }^{54}$ and Italian historians have considered corsairing as a major and specific feature of Barbary maritime economies. ${ }^{55}$ Postcolonial Algerian historians have interpreted corsairing as a violent response to the progressive exclusion of Maghreb ships from Mediterranean shipping dominated by the European powers ${ }^{56}$ - a kind of anticipated resistance to a future colonial regime. ${ }^{57}$

The image of violent state-building through military conquest or usurpation, present in the expression 'Barbary States' with its connotations of illegitimate state-building, ${ }^{58}$ and the violent origins of the riches of the rulers and the elites of these 'Corsairs' Republics,' is supported by the prominent roles and extraordinary careers of some corsairs, converts to Islam, at the apogee of corsairing (1580-1660). At this time, we find Māmī Arnawț, an Albanian convert and commander of the Algerian fleet, who captured Miguel Cervantes in 1575 and specialised in the ransoming business. ${ }^{59}$ We also find 'Alī Bičenīn, who in the 1630 s was the most important slave merchant in the Maghreb and in 1638 destroyed the Bastion de France, a French concession for coral-fishing on the Algerian coast, with his private fleet, taking many captives. One year later, he took 1000 captives in a raid on the Calabrian coast. In Tunis, a convert from Albisola, near Savona (Liguria), Ustā Murād or Osta Moratto Genovese, became one of the most famous corsairs and the commander of the galleys of Bizerta before becoming the dey of Tunis (1637-40). Engaged in the slave trade, the ransoming business and the recycling of booty, he acquired landed property around and in Tunis, mamluks (slaves) and was present in trade tout court, selling for instance sugar to Corsican merchants in Livorno.

But these extraordinary adventures of Christian renegades do not give a realistic impression of the complex realities of power and its economic foundations. North African corsairing experienced contrasting developments: the Moroccan Sultan enforced state control of armament and 


\section{Proof}

corsairing at the end of the seventeenth century, ${ }^{60}$ while in Tunis in the second half of the eighteenth and at the beginning of the nineteenth centuries, only one-quarter of corsairing was due to the state-organised corsairing and three-quarters was financed by private investors. ${ }^{61}$ Recent research on Algiers, Tunis and Tripoli has also shown the relatively limited significance of corsairing compared to other economic sectors and has highlighted the intense and mainly peaceful trade with the European shores of the Mediterranean, as well as the asymmetries that worked to the disadvantage of the merchants of North Africa and the inhospitality towards them in the European ports. ${ }^{62}$ For example, the Regency of Algiers in the eighteenth century became a place of massive exportation of grain to France, ${ }^{63}$ and the Regency of Tunis in the seventeenth century was largely integrated in the trade networks of the Western Mediterranean encompassing Tunis, Livorno and Marseilles. ${ }^{64}$

Why did the Europeans not eliminate these 'nests of pirates', always accused of not respecting the treaties concluded? Why did they, on the contrary, continue to negotiate, to conclude peace and commercial treatises, to pay tributes, to offer presents and to kiss the hand of the dey? The first reason, as it appears in the contemporary diplomatic sources, is that the European powers tried to direct Barbary corsairing against their European competitors and thus to obtain an advantageous position. An informal agent reported in 1663 to Louis XIV that the Algerians could not live and survive without piracy; if the king of France would conclude a peace treaty with them, 'they would make war with all the other States and would break the peace with England, which would have important consequences in the actual conjuncture' ${ }^{65}$ This was a shared argument, as the authorities in North Africa sought not to be at peace with all European powers at the same time, something that explains the survival of corsairing up to the beginning of the nineteenth century. ${ }^{66}$ Second, a privileged position in the Ottoman Regencies in Northern Africa would give access to the very profitable market of the recycling of booty between Algiers, Tunis, Livorno, Genoa and Marseilles.

A third reason was the relationship of the Regencies to the Ottoman Empire. One of the main interests of the European powers engaged in the Levant trade and Mediterranean shipping was to obtain advantageous terms of trade in the Ottoman Empire and to extend protection for European merchants. A major change in the sixteenth-century Mediterranean was the expansion of the Ottoman Empire, which placed Algiers, Tunis and Tripoli under the distant suzerainty of Constantinople. As the 'Capitulations' - a unilateral act of grace, according protection and privileges to the Europeans - given by the Sultan to France in 1569, 


\section{Proof}

Corsairing in the Early Modern Mediterranean

81

England in 1580/1583 and the Dutch in 1612 did not ensure efficient protection against attacks by the Ottoman Regencies in the Maghreb, the European powers began progressively, starting with France and Tunis in 1605 , to negotiate treaties of peace and commerce directly with the Regencies. Although Ottoman suzerainty was reaffirmed in the opening of these treaties in the seventeenth century and invoked in the negotiations, for instance with Hamburg in the eighteenth century, the North African Regencies nevertheless became autonomous actors (personae morales) in diplomatic relations.

European authors continued to denounce the North African Regencies as 'nests of pirates' and their actitivies as 'African banditry', but the competing European powers, most prominently France, the Netherlands and England, all concluded peace treaties with the Ottoman Regencies in the seventeenth century and, outside Ottoman suzerainty, with the Sultan of Morocco. These relations became a laboratory for the evolution of the law of the sea and the law of nations, and European authors gradually began to recognise the changes in the jurisprudence of the concluded treaties. The Irish lawyer Charles Molloy in 1682, in the third edition of his De Jure Maritimo et Navali, registered the shift in the position and treatment of 'Pirates that have reduced themselves into a Government of State, as those of Algier, Sally, Tripoli, Tunis, and the like' who should not 'obtain the rights of solemnities of war.' '[N]otwithstanding this', he continued:

Tunis and Tripoli and their Sister Algier do at this day (though Nests of Pirates) obtain the right of Legation' demonstrated by the treaties concluded by Britain with Tunis and Tripoli. This makes them not Pirates (enemies of mankind) but gives them the status of enemies (in war): So that now (though indeed Pirates) yet having acquired the reputation of a Government, they cannot properly be esteemed Pirates but Enemies. ${ }^{67}$

In 1737, the Dutch theorist of the law of nations Cornelius van Bynkershoek offered the clearest statement on the nature and sovereignty of the North African states:

The peoples of Algiers, Tripoli, Tunis, and Salee are not pirates, but rather organized states, which have a fixed territory in which there is an established government, and with which, as with other nations, we [i.e. the Staten-General] are now at peace, now at war. Hence they seem to be entitled to the rights of independent states. ${ }^{68}$ 


\section{Proof}

82

Persistent Piracy

Still, the Dutch jurist made use of a kind of jurisprudential law of nations, and the eighteenth-century theorists and compilers of a ius publicum europaeum considered a 'law of Barbary' differing from the European tradition. This should be linked to the major shift in power relations between the European powers and the Maghreb states in the second half of the seventeenth century, with the imposition of treatises on the three Regencies by England in the 1660s and the use of massive military violence - successive bombardings of Algiers in 1682, 1683 and 1688 - by France. ${ }^{69}$

The imposition of 'terms of trade' on the regencies, which could be called a juridical Europeanisation, ${ }^{70}$ somewhat paradoxically made corsairing and ransoming a fabric of legal regulation and pragmatic innovation, leading to quite efficient paper protection. This comprised not only safe-conducts and trading licenses (salvacondotti, patente, congé, charte-partie, bolletini di sanità), lists of passengers and cargo and bills of lading (police de chargement, and so on), all of which were necessary for navigation and for entering the ports of the Mediterranean, but also the invention of 'Turkish passports' for ships from Denmark and Sweden and passaventi, sold by the French consuls in the Mediterranean ports, allowing verification of the origin of the ship in the North African ports. ${ }^{71}$ An even more astonishing feature of this invention of a 'sea of paper' were the certificates delivered by the French consul to the corsairs of Algiers or Tunis, attesting their quality and role in legitimate warfare, thereby distinguishing them from ordinary sea robbers or pirates.

Perhaps the most important innovation - introduced at the turn of the seventeenth century in the Capitulations accorded to France in 1597 and 1604, in the treaty between Tunis and France (1605), in that of Algiers with the Dutch Republic (1612) and reaffirmed in the treaties of the 1670s with Algiers and Tunis (France, England, the Dutch Republic) - was the principle that the flag of the ship protected not only the vessel itself but also the cargo belonging to subjects of enemy states (free ships-free goods). This principle was essential for the powers engaged in shipping, and in particular for neutral states. Thus, authors discussing the protection of neutral ships recognised, in a positive sense, the existence and practice of a 'maritime law of the Barbaresques'. The North African corsairs, conceded the Danish Martin Hübner in his thesis De la Saisie des bâtiments neutres (On the Seizure of Neutral Vessels; 1759), respected the law of nations by waging war only on their enemies - Portugal, Spain and other Christian European states. Still calling them 'plunderers of the sea', he explained that the 'Barbaresques . . . never engaged in hostile behaviour with friendly and neutral ships 


\section{Proof}

Corsairing in the Early Modern Mediterranean

regarding the ownership of their cargos .... [T]he Danish, French, Swedish, English and Dutch flags provide adequate protection for the cargos. ${ }^{72}$ The introduction of this principle, accepted more generally only in the nineteenth century, was accompanied by another innovation, claimed insistently by all powers present in the Mediterranean: the limitation of the rights of authorities to board and visit ships only for the purpose of formal visits and the control of documents. ${ }^{73}$

The abstract principle of protection was difficult to accept as it was contrary to the customs of the sea, according to which the cargo of the enemy was considered a legitimate booty, and the concrete procedures of control were the object of divergent interpretations in different legal traditions and practices. The European topos of the 'Barbaresques' as notoriously unreliable, treaty-breaking pirates was not only far from reality - their corsairing was perhaps the best regulated of all in the seventeenth and eighteenth centuries in the Western Mediterranean but the topos was also an ideological expression of the asymmetries in the relations between the European powers and the Ottoman Regencies. The lack of respect and recognition of honour and rank demonstrated by the European powers was a constant source of complaint of the North African authorities, a circumstance that concurs with French sources from the time of Louis XIV, who explicitly ordered that the Maghreb Regencies should not be treated as equals. Evidence can be found for the increasing inhospitality of European ports to Muslim merchants from the Maghreb and the Levant, and there was a marked lack of reciprocity concerning the right to free exercise of religion for Christians in North Africa compared with Muslims in European ports. ${ }^{74}$

In 1674, the dey of Algiers demanded that 'Turks' captive in Genoa, Livorno or Spain who had fled to France, with which Algiers was at peace, should not be enslaved or put on the galleys again. ${ }^{75}$ We can find examples of this practice in the petitions of Algerian slaves on Genoese galleys addressed to the dey of Algiers: they had escaped from the Genoese galleys and had fled to ships 'under the flag of France because of the peace' but were subsequently sold back to Genoa. ${ }^{76} \mathrm{~A}$ permanent reason for frictions and complaints was due to the fact that the French consul at Livorno was authorised by Louis XIV to buy Algerian slaves for the French galleys at Toulon - during peacetime with Algiers!

Frictions were the fruit of different interpretations of the nature of the treaties, considered by the authorities on the Maghreb coast as an expression of personal friendship, an 'amity pact' (pacte d'amitie) that had to be constantly confirmed by visible signs and public attitude. Thus, misunderstandings or misinterpretations of gestures as aggressive 


\section{Proof}

\section{Persistent Piracy}

postures in the context of an encounter at sea or the boarding of a ship could end in a violent fight and capture. A question not resolved by the treaties was the presence of passengers of a different origin to that of the ship, as signalled by its flag: 'If we find two or three strangers on a French ship, we don't say anything. But if there are more, we will capture our enemies without touching the cargo,' explained the dey of Algiers in 1674 to the French king. At the same time, the dey declared that French passengers on ships from Livorno, Genoa, Portugal, Spain, Holland or Malta were to be considered as enemies and would be captured and enslaved. Living for 20 or 30 years in the country of an enemy and having married there, they had served the enemy and engaged in corsairing with him. Consequently, they were no more seen and accepted as subjects of the French king. ${ }^{77}$

Increasing regulation, the production of certificates and other documents and the invention of procedures thus could not eliminate the uncertainties linked with multiple identities and divergent interpretations of rules and behaviour. Papers and procedures even created new possibilities for their opportunistic use and misuse or fraud. Indeed, a traffic with false documents and flags made the fortune of some port cities in the Atlantic and the Mediterranean, such as the 'Republic of Seven Flags' (Ragusa/Dubrovnik).

Yet if we seek 'persistent piracy' - the porosity of the distinction between corsairing, piracy and maritime violence in the interstices of naval warfare - it is not to North Africa but to the Aegean Sea and the archipelago of the Cyclades that we should look. These islands passed in 1540 under Ottoman rule but were difficult to control efficiently the habitants often paid just the $\underline{k} h a r a \bar{a} \underline{j} j$ (tribute) to recognise Ottoman domination, and in war times, a tribute to Venice. In the second half of the sixteenth century, the archipelago became the theatre of Christian corsairing by the Knights of St John and St Stephen. A second period of mainly Christian corsairing was linked to the great wars of Candia (1645-69) and Morea (1684-99) between Venice and Constantinople. Privateers operated under the flag of Venice (from Dalmatia), Livorno (from Corsica), Malta (many from Provence) and so on. Many stayed on after the wars and the return of the isles to Ottoman rule, acting as true insular entrepreneurs of violence with little respect for the formal documents of the Ottomans, regardless of whether they were Turks, Greeks, Armenians or Jews, or the Europeans they despoiled, selling their booty at Malta or Livorno. During the Morean War the archipelago became a theatre of the War of the Great Alliance (1688-97), with intense attacks by English, Dutch, Portuguese and Mallorquin corsairs on French 


\section{Proof}

merchant ships. Corsairing diminished in the eighteenth century, but some French and Corsican entrepreneurs of violence still operated in the Aegean Sea under different flags, such as those of Venice, Livorno and Portugal. ${ }^{78}$

This was a liminal situation, perhaps the most resembling to the somewhat romantic expectations and visions of pirates and their 'republics' as alternatives to Early Modern state-formation. The reality was less romantic, however. In the Early Modern Mediterranean, as in other maritime spaces, sea robbery followed, as part-time activity in critical or desperate situations, economic and political conjunctures. As such, it was and remained a persistent social phenomenon but was of little consequence to regional maritime trade. Corsairing, though, as the legitimate exercise of violence and a 'secondary war' against enemies, highlights the inherent violence of state-building and its weaknesses, to be compensated with the mobilisation of private resources in warfare. It was as 'in-laws', inside the complex structures of power, in the context of competing claims to the exercise of jurisdiction and imperium, in a polycentric Mediterranean, that famous corsairs could assemble riches and make social and political careers, even to the point of becoming commanders of the Ottoman fleet and governors of Ottoman Regencies. It was with the Barbary corsairs - accused in European sources of violent usurpation of power and of being by nature untrustworthy - that the European powers developed the earliest modern forms of regulation and protection of the freedom of navigation and trade. The vector of this transformation of the Mediterranean was violence - the canons of the British and French vessels bombarding Algiers - which sustained a juridical Europeanisation of the Inner Sea.

In the sixteenth century, a commander of the Ottoman fleet was presented with a salvacondotto by a merchant when he visited a captured ship. He refused to have a look at it, saying 'this paper is for corsairs'. A century later, everyone had paper documents, also the Aegean pirates, and they had even too many. It was with the regulation of corsairing and the repression of piracy that the Mediterranean became a sea of paper, which seems to be a sign of modernity.

\section{Notes}

1. C. Schmitt, Der Nomos der Erde im Völkerrecht des Jus Publicum Europaeum (The Nomos of the Earth in European Public Law), 5th edn (Berlin: Duncker and Humblot, 2011 [1950]), pp. 143-6.

2. Hugo Grotius and his contemporary adversaries were aware of it; see the work of Martine van Ittersum and Peter Borschberg. 


\section{Proof}

Persistent Piracy

3. D. Heller-Roazen, The Enemy of All: Piracy and the Law of Nations (New York: Zone Books, 2009).

4. See S. D. Goitein, A Mediterranean Society: The Jewish Communities of the Arab World as Portrayed in the Documents of the Cairo Geniza, 5 vols (Berkeley, CA: University of California Press, 1967), in particular Vol. 1, Economic Foundations.

5. Schmitt, Nomos der Erde, p. 150, even calling it a 'war'.

6. F. de Vivo, 'Historical Justifications of Venetian Power in the Adriatic', Journal of the History of Ideas, 64:2 (2003), pp. 159-76.

7. J. E. Thompson, Mercenaries, Pirates and Sovereigns: State-Building and Extraterritorial Violence in Early Modern Europe (Princeton, NJ: Princeton University Press, 1994).

8. H. S. Khalilieh, Islamic Maritime Law: An Introduction (Leyden: Brill, 1998); ibid., Admiralty and Maritime Laws in the Mediterranean Sea (ca.800-1500): The Kitāb Akriyat al-Sufun vis-à-vis the Nomos Rhodion Nautikos (Leiden: Brill, 2006); and V. Panaite, The Ottoman Law of War and Peace: The Ottoman Empire and Tribute Payers (Boulder, CO: East European Monographs, 2000).

9. J. F. Chanet and C. Windler (eds), Les Ressources des faibles: neutralités, sauvegardes, accommodements en temps de guerre (XVIe-XVIIIe siècles) (The Resources of the Weak: Neutrality, Security Agreements and Accommodation in Times of War (16th-18th Centuries) (Rennes: Presses Universitaires de Rennes, 2009).

10. D. Valérian, Bougie, port maghrébin, 1067-1510 (Béjaïa, a Maghreb Port, 1067-1510) (Rome: École Française de Rome (EFR), 2006), pp. 436-8.

11. M. D. López Pérez, La Corona de Aragón y el Maghreb en el siglo XIV (1331-1410) (The Crown of Aragon and Maghreb in the 14th Century (1331-1410)) (Barcelona: Institución Milá y Fontanals, 1995), p. 579.

12. H. Bresc, 'Course et Piraterie en Sicile (1250-1450)' (Corsairing and Piracy in Sicily (1250-1450)), Anuario de Estudios Medievales, 10 (1980), p. 753.

13. Valérian, Bougie, pp. 84-5 and 453.

14. V. Piergiovanni (ed.), Corsari e riscatto dei Captivi (Corsairs and the Ransom of Captives) (Milan: Giuffré, 2010), p. 3.

15. F. Guerrero, Voyage à Jérusalem (Voyage to Jerusalem), French trans. by O. Trachier (Grenoble: Jérôme Million, 1997 [1611]), p. 144.

16. Archives départementales de Bouches-du-Rhône (AD BdR), 351 E 470 fol. $647 \mathrm{v}$ (10 February 1498).

17. AD BdR, $380 \mathrm{E} \mathrm{12,} \mathrm{fol.} \mathrm{263r} \mathrm{(November} \mathrm{1512).}$

18. Thompson, Mercenaries, Pirates and Sovereigns; and A. Pérotin-Dumon, 'The Pirate and the Emperor: Power and the Law on the Seas, 1450-1850', in J. D. Tracy (ed.), The Political Economy of Merchant Empires (Cambridge: Cambridge University Press, 1991), pp. 196-221.

19. F. Redlich, De praeda militari: Looting and Booty 1500-1815 (Wiesbaden: F. Steiner, 1956); and K. R. Andrews, Trade, Plunder and Settlement: Maritime Enterprise and the Genesis of the British Empire, 1480-1630 (Cambridge: Cambridge University Press, 1984).

20. H. de Valbelle, Histoire journalière (1498-1539) (Daily History (1498-1539), Vol. 2, ed. by V.-L. Bourilly (Aix-en-Provence: Université de Provence, 1985), p. 210.

21. J. Glete, Warfare at Sea, 1500-1650: Maritime Conflicts and the Transformation of Europe (London: Routledge, 2000), p. 72. But see S. Subrahmanyam, Improvising Empire: Portuguese Trade and Settlement in the Bay of Bengal, 


\section{Proof}

Corsairing in the Early Modern Mediterranean 87

1500-1700 (Oxford: Oxford University Press, 1990); and recently S. R. Prange, 'The Contested Sea: Regimes of Maritime Violence in the Pre-Modern Indian Ocean', Journal of Early Modern History, 17 (2013), pp. 9-33.

22. L. Benton, A Search for Sovereignty: Law and Geography in European Empires, 1400-1900 (Cambridge: Cambridge University Press, 2010), ch. 3.

23. F. C. Lane, 'Economic Consequences of Organized Violence', Journal of Economic History, 18 (1958), pp. 401-17; and ibid., Profits from Power: Readings in Protection Rent and Violence-Controlling Enterprises (Albany, NY: State University of New York Press, 1979). See also C. Tilly, 'War-Making and State-Making as Organized Crime', in P. B. Evans, D. Rueschemeyer and T. Skocpol (eds), Bringing the State Back In (Cambridge: Cambridge University Press, 1985), pp. 169-91.

24. On European naval warfare and corsairing in the Mediterranean, see R. Cancila (ed.), Mediterraneo in armi: secc. XV-XVIII (The Mediterranean in Arms: 15th-18th Centuries), 2 vols (Palermo: Associazione Mediterranea, 2007); J. S. Corbett, England in the Mediterranean: A Study of the Rise and Influence of British Power within the Straits, 1603-1713, 2nd edn (London: Longmans, Green and Co., 1917); R. C. Anderson, Naval Wars in the Levant, 1559-1853 (Liverpool: University Press, 1952); K. R. Andrews, Elizabethan Privateering: English Privateering during the Spanish War, 1585-1603 (Cambridge: Cambridge University Press, 1964); D. Delison Hebb, Piracy and the English Government, 1616-1642 (Aldershot: Scolar Press, 1994); K. Digby, Journal of a Voyage into the Mediterranean, A.D. 1628, ed. by J. Bruce (London: Publications of the Camden Society, 1868); C. Carrière, Négociants marseillais au XVIIIe siècle: Contribution à l'étude des économies maritimes (Marseillan Merchants in the 18th Century: Contribution to the Study of Maritime Economies), Vol. 1 (Marseille: Institut Historique de Provence, 1973); G. López Nadal, El corsarisme mallorquí a la Mediterrània occidental, 1652-1698: un comerç forçat (Mallorcan Corsairing in the Western Mediterranean, 1652-1698: A Forced Trade) (Ciutat de Palma: Conselleria d'Educació i Cultura del Govern Balear, 1986); and L. Lo Basso, In traccia de' legni nemici: Corsari europei nel Mediterraneo del Settecento (In Search of the Enemies' Ships: European Corsairs in the Eighteenth Century) (Ventimiglia: Philobiblon, 2002).

25. J. M. Witt, 'Die Rolle der Kaperei in der europäischen Seekriegsgeschichte' (The Role of Privateering in the European History of War at Sea), in S. Förster, C. Jansen and G. Kronenbitter (eds), Rückkehr der Condottieri? Krieg und Militär zwischen staatlichem Monopol und Privatisierung: Von der Antike bis zur Gegenwart (Paderborn: F. Schöningh, 2010), p. 82.

26. Carrière, Négociants marseillais; and López Nadal, El corsarisme mallorqui.

27. Fernand Braudel, The Mediterranean and the Mediterranean World in the Age of Philip II (Berkeley and Los Angeles, CA: University of California Press, 1995 [1966]), Vol. 2, pp. 865-91.

28. A. Rieger, Die Seeaktivitäten der muslimischen Beutefahrer als Bestandteil der staatlichen Flotte während der osmanischen Expansion im Mittelmeer im 15. und 16. Jahrhundert (The Maritime Activities of the Muslim Freebooters as Part of the State Navy during the Ottoman Expansion in the Mediterranean in the 15th and 16th Centuries) (Berlin: Klaus Schwarz Verlag, 1994).

29. G. Restifo, 'Le Sac de Lipari (1544)' (The Sack of Lipari (1544)), in A. Brogini and M. Ghazali (eds), Des Marges aux frontières: les puissances et les îles en Méditerranée à l'époque moderne (Paris: Garnier, 2010), pp. 59-80. 


\section{Proof}

Persistent Piracy

30. M. Mafrici, Mezzogiorno e pirateria nell'età moderna (secoli XVI-XVIII) (Southern Italy and Piracy in the Modern Era (14th-18th Centuries)) (Naples: Edizioni Scientifiche Italiane, 1995), pp. 95-6.

31. '[S]i sono alzati Bandiere di fede ... e si riscattavano schiavi', Biblioteca nazionale centrale (BNC), Florence, Fondo Nazionale II.IV.310 fol. 185r-186v (1598).

32. F. Andújar Castillo, 'Los rescates de cautivos en las dos orillas del Mediterráneo y en el mar (Alafías) en el siglo XVI' (The Ransom of Captives on Both Sides of the Mediterranean and at Sea (Alafías) in the 17th Century), in W. Kaiser (ed.), Le Commerce des captifs: les intermédiaires dans l'échange et le rachat des prisonniers en Méditerranée, XVe-XVIIe siècles (Rome: École Française de Rome (EFR), 2008), pp. 135-64.

33. G. Dávid and P. Fodor (eds), Ransom Slavery along the Ottoman Borders (Early Fifteenth-Early Eighteenth Centuries) (Leiden: Brill, 2007).

34. M. Fontenay and A. Tenenti, 'Course et piraterie méditerranéennes de la fin du Moyen Age au début du XIXe siècle' (Mediterranean Corsairing and Piracy from the End of the Middle Ages to the Early 19th Century), Course et piraterie, 2 (1975), pp. 87-136.

35. P. Boyer, 'Les Renégats et la marine de la Régence d'Alger' (The Renegades and the Navy of the Regency of Algiers), Revue de l'Occident musulman et de la Méditerranée, 39 (1985), pp. 93-106.

36. For the French galleys, see A. Zysberg, Les Galériens: vies et destins de 60,000 forçats sur les galères de France, 1680-1748 (The Galley Slaves: The Lives and Destinies of 60,000 Convicts on the French Galleys, 1680-1748) (Paris: Le Seuil, 1987).

37. L. A. Anaya Hernández, 'Simón Romero, pescador gran canario y gran almirante de la armada argelina' (Simón Romero, Fisherman from Grand Canaria and Grand Admiral of the Algiers Navy), Anuario de estudios atlánticos, 49 (2003), pp. 1-21; and ibid., Moros en la costa: Dos siglos de corsarismo berberisco en las Islas Canarais (1569-1749) (Moors on the Coast: Two Centuries of Barbary Corsairing in the Canary Islands (1569-1749)) (Las Palmas de Gran Canaria: Instituto Universitario de Educación a Distancia (UNED), 2006).

38. See M. Ressel, 'The North European Way of Ransoming: Explorations into an Unknown Dimension of the Early Modern Welfare State', Historical Social Research, 35:4 (2010), pp. 125-47; and the contributions of Joachim Östlund, Erik Gøbel and Leos Müller in the same issue.

39. R. C. Davis, Christian Slaves, Muslim Masters: White Slavery in the Mediterranean, the Barbary Coast, and Italy, 1500-1800 (Basingstoke: Palgrave Macmillan, 2003), p. 38.

40. D. Panzac, Les Corsaires barbaresques: la fin d'une épopée, 1800-1820 (The Barbary Corsairs: The End of an Epic, 1800-1820) (Paris: Centre National de la Recherche Scientifique (CNRS), 1999), p. 25, based on G. Fisher, Barbary Legend: War, Trade and Piracy in North Africa, 1415-1830, (Oxford: Clarendon Press, 1957), p. 190.

41. S. Boubaker, La Régence de Tunis au XVIIe siècle: ses relations commerciales avec les ports de l'Europe méditerranéenne, Marseille et Livourne (The Regency of Tunis in the 17th Century: Its Commercial Relations with the European Mediterranean Ports) (Zaghouan: Centre d'Études et de Recherches Ottomanes et Morisco 


\section{Proof}

Corsairing in the Early Modern Mediterranean 89

89

Andalous (CEROMA), 1987), p. 45, based on Archives de la Chambre de Commerce et d'Industrie de Marseille (ACCIM), E 60, 61, 80.

42. G. van Krieken, Corsaires \& marchands: les relations entre Alger et les Pays-Bas, 1604-1830 (Corsairs and Merchants: The Relations between Algiers and the Netherlands, 1604-1830) (Paris: Éditions Bouchene, 2002 [1999]), p. 26.

43. C. R. Pennell (ed.), Piracy and Diplomacy in Seventeenth-Century North Africa: The Journal of Thomas Baker, English Consul in Tripoli, 1677-1685 (London: Associated University Presses, 1989), pp. 40-1 and 46-9.

44. M. Fontenay, La Méditerranée entre la Croix et le Croissant: navigation, commerce, course et piraterie (XVIème-XIXème siècle) (The Mediterranean between the Cross and the Crescent: Navigation, Commerce, Corsairing and Piracy (16th-19th Century) (Paris: Garnier, 2010), p. 303.

45. Fontenay, La Méditerranée, ch. 7; and L. Merouche, La Course, mythes et réalité: recherches sur l'Algérie à l'époque ottomane (Corsairing, Myths and Reality: Research on Algeria in Ottoman Times) (Saint-Denis: Bouchène, 2007).

46. M. Fontenay, 'Corsaires de la foi ou rentiers du sol? Les chevaliers de Malte dans le corso méditerranéen au XVIIème siècle' (Corsairs of the Faith or Tenants of the Land? The Knights of Malta in the Mediterranean Corsairing in the 17th Century), Revue d'histoire moderne et contemporaine, 35 (1988), pp. 361-84. This is contradictory to the findings of Anne Brogini on the benefits of the Maltese corso, see A. Brogini, Malte, frontière de chrétienté: 1530-1670 (Malte, Frontier of Christendom: 1530-1670) (Rome: École Française de Rome (EFR), 2006), pp. 311, 317 and 483. See also A. Hoopen, 'The Finance of the Order of St. John in the Sixteenth and Seventeenth Centuries', Europe Studies Review, 2 (1973), pp. 103-19.

47. Andrews, Trade, Plunder and Settlement, p. 246.

48. F. Angiolini, I Cavalieri e il Principe (The Knights and the Prince) (Florence: Edifir, 1996).

49. C. Vassallo, Corsairing to Commerce: Maltese Merchants in XVIIIth-Century Spain (La Valette: Malta University Publishers, 1997).

50. G. Poumarède, Pour en finir avec la Croisade: mythes et réalités de la lutte contre les Turcs aux XVIe et XVIIe siècles (Beyond the Crusades: Myths and Realities in the Struggle against the Turks in the 16th and 17th Centuries) (Paris: Presses Universitaires de France, 2004), pp. 459-529.

51. W. Kaiser, 'Frictions profitables: L'économie de la rançon en Méditerranée occidentale (XVIe-XVIIe siècles)' (Profitable Frictions: The Economy of Ransoming in the Western Mediterranean (16th to 17th Centuries)), in S. Cavaciocchi (ed.), Ricchezza del mare, Ricchezza dal mare, secc. XIII-XVIII (Florence: Le Monnier, 2006), Vol. 2, pp. 689-701; and W. Kaiser, 'Les "hommes de crédit" dans les rachats des captifs provençaux, XVIe-XVIIe siècles' (The 'hommes de crédit' in the Ransoming of Provencal Captives, 16th-17th Centuries), in W. Kaiser (ed.), Le Commerce des captifs, pp. 291-319.

52. Davis, Christian Slaves, p. 23.

53. D. Panzac, La Marine ottomane: de l'apogée à la chute de l'Empire (1572-1923) (The Ottoman Navy: From the Apogee to the Fall of the Empire (15721923)), (Paris: Centre National de la Recherche Scientifique (CNRS), 2009), p. 138. 


\section{Proof}

54. T. Bachrouch, Formation sociale barbaresque et pouvoir à Tunis au XVIIe siècle (Barbary Social Formation and Power in Tunis in the 17th Century) (Tunis: Publications de l'Université de Tunis, 1977). See also A. Raymond, Tunis sous les Mouradites: la ville et ses habitants au XVIIe siècle (Tunis under the Mouradites: The City and its Inhabitants in the 17th Century) (Tunis: Cérès, 2006).

55. C. Manca, 'Problemi aperti sul commercio e sul riscatto degli schiavi cristiani nel Mediterraneo dopo Lepanto' (Unresolved Problems Concerning Trade and the Ransom of Christian Slaves in the Mediterranean after Lepanto), Africa, 29 (1974), pp. 549-72; and ibid., Il modello di sviluppo economico delle città marittime barbaresche dopo Lepanto (The Model of Economic Development of the Barbarian Maritime Cities after Lepanto) (Naples: Facoltà di economia marittima, Istituto universitario navale, 1982).

56. This argument was already developed by M. Emerit, 'L'Essai d'une marine marchande barbaresque au XVIIIe siècle' (Trying to Build a Barbary Merchant Navy in the 18th Century), Cahiers de Tunisie, 11 (1955), pp. 363-70; and J. Mathiex, 'Sur la marine marchande barbaresque au XVIIIe siècle' (On the Barbary Merchant Navy in the 18th Century), Annales: Économies, sociétés, civilisations, 13:1 (1958), pp. 87-93.

57. M. Belhamissi, Les Captifs algériens et l'Europe chrétienne (The Algerian Captives and Christian Europe) (Algiers: Entreprise nationale du livre, 1988).

58. For a refutal of this 'black legend', see S. Bono, I corsari barbareschi (The Barbary Corsairs) (Turin: Edizioni RAI Radiotelevisione Italiana (ERI), 1964); ibid., Corsari nel Mediterraneo (Corsairs in the Mediterranean) (Milan: Arnold Mondadori, 1993); G. Fisher, Barbary Legend: War, Trade and Piracy in North Africa, 1415-1830 (Oxford: Clarendon Press, 1957).

59. W. Kaiser, 'Una missione impossibile? Riscatto e comunicazione nel Mediterraneo Occidentale (secoli XVI-XVII)' (A Mission: Impossible? Ransom and Communication in the Western Mediterranean (16th-17th Centuries), in W. Kaiser and B. Salvemini (eds), Special Issue: 'Informazioni e scelte economiche', Quaderni storici, 124:1 (2007), pp. 19-41.

60. L. Maziane, Salé et ses corsaires (1666-1727): Un port de course marocain au XVIIe siècle (Salé and its Corsairs (1666-1727): A Moroccan Corsairing Port in the 17th Century) (Caen: Presses Universitaires de Caen, 2007), pp. 149-51.

61. P. Sebag, La Course tunisienne au XVIIIe siècle (The Tunisian Corsairing in the 18th Century) (Tunis: Presses de l'Université de Tunis, 2001).

62. W. Kaiser, 'Asymétries méditerranéennes: Présence et circulation de marchands entre Alger, Tunis et Marseille' (Mediterranean Asymmetries: Presence and Circulation of Merchants between Algiers, Tunis and Marseille), in J. Dakhlia and B. Vincent (eds), Les Musulmans dans l'histoire de l'Europe, Vol. 1: Une Intégration invisible (Paris: Albin Michel, 2011), pp. 417-42.

63. I. Touati, Le Commerce du blé entre l'Algérie et la France à l'époque ottomane (XVIe-XIXe siècles) (The Grain Trade between Algeria and France in the Ottoman Era (16th-19th Centuries)) (originally PhD thesis, Université Paris IV, 2009) (Paris: Bouchène, 2014, forthcoming).

64. S. Boubaker, 'Négoce et enrichissement individuel à Tunis du XVIIème siècle au début du XIXème siècle' (Trade and Individual Enrichment in Tunis from the 17th Century until the Early 19th Century), Revue d'histoire moderne et 


\section{Proof}

Corsairing in the Early Modern Mediterranean 91

contemporaine, 50:4 (2003), pp. 29-62; and ibid., La Régence de Tunis au XVIIe siècle.

65. Fontenay, La Méditerranée, p. 329.

66. Panzac, Les Corsaires barbaresques.

67. C. Molloy, De Jure Maritimo et Navali or, a Treatise of Affaires Maritime, and of Commerce in Three Books (London: John Bellinger, 1682), pp. 54-5, quoted in G. Calafat, 'Ottoman North Africa and ius publicum europaeum: The Case of the Treaties of Peace and Trade (1600-1750)', in A. Alimento (ed.), War, Trade and Neutrality: Europe and the Mediterranean in the Seventeenth and Eighteenth Centuries (Milan: Franco Angeli, 2011), pp. 178-9.

68. C. van Bynkershoek, Quaestionum juris publici libri due (Questions of Public Law in Two Books) (Oxford: Clarendon Press, 1930 [1937]), ch. 17, quoted in Calafat, 'Ottoman North Africa', p. 182.

69. In the 1680s, Algiers had 562 canons (1681) or 680 canons (1682) on its ships. In comparison, the English Navy disposed in 1689 of 323 ships with 9912 canons; see Merouche, La Course, p. 163.

70. C. Windler, 'De la 'Normalisation' à la soumission: les relations francomaghrébines au XVIIIe et au début du XIXe siècle' (From 'Normalisation' to Submission: The Relations between France and the Maghreb in the 18th and the Beginning of the 19th Century), in Kaiser (ed.), Le Commerce des captifs, pp. 345-63.

71. M. Ressel, Zwischen Sklavenkassen und Türkenpässen: Nordeuropa und die Barbaresken in der frühen Neuzeit (Between Slave Funds and Turk Passes: Northern Europe and the Barbary States in the Early Modern Era) (Berlin: De Gruyter, 2012).

72. M. Hübner, De la Saisie des bâtiments neutres, ou du droit qu'ont les nations belligérantes d'arrêter les navires des peuples amis (On the Seizure of Neutral Vessels, or On the Right which Nations in War Have to Interrupt the Vessels of Friendly Nations) (The Hague, 1759), Vol. 2, pp. 223-4.

73. Ibid., pp. 224-5, referring to the treaties between Algiers and the Dutch Republic in 1726 and 1757.

74. Kaiser, 'Asymétries méditerranéennes'.

75. Letter of Hadji Mohammed, dey of Algiers, to Louis XIV (Algiers, 23 September 1674), in E. Plantet (ed.), Correspondance des deys d'Alger avec la cour de France, 1579-1833 (Correspondance from the Deys of Algiers with the Court of France, 1596-1833), Vol. 1: 1579-1700 (Paris, 1889), pp. 72-3.

76. Archives de la Chambre de Commerce et d'Industrie de Marseille, G 51: Coppie de la lettre de 4. Esclaves d'alger qui sont sur les galleres de gennes escritte au dey de ce Royaume (translation by the royal translator in Marseilles).

77. Letter of Hadji Mohammed, dey of Algiers, to Louis XIV (Algiers, 23 September 1674), Plantet, Correspondance, pp. 72-3.

78. G. Koutzakiotis, 'Les Cyclades au XVIIe siècle: une entreprise de la course chrétienne dans l'empire Ottoman' (The Cyclades in the 17th Century: A Christian Corsairing Enterprise in the Ottoman Empire), in Brogini and Ghazali (eds), Des Marges aux frontières, pp. 231-41; Fontenay, La Méditerranée, pp. 357-406; M. Greene, Catholic Pirates and Greek Merchants: A Maritime History of the Early Modern Mediterranean (Princeton, NJ: Princeton 


\section{Proof}

92 Persistent Piracy

2

4

6

11

12

13

14

15

16

17

18

19

20

21

22

23

24

25

26

27

28

29

30

31

32

33

34

35

36

37

38

39

40

41

University Press, 2010); Panzac, La Marine ottomane; B. J. Slot, Archipelagus turbatus: les Cyclades entre colonisation latine et occupation ottomane (Disturbed Archipelago: The Cyclades between Latin Colonization and Ottoman Occupation) (Istanbul: Nederlands Historisch-Archaeologisch Instituut te Istanbul, 1982); and G. Veinstein and N. Vatin (eds), Insularités ottomanes (Ottoman Insularities) (Paris: Maisonneuve and Larose, 2004). 